\title{
Strategies to evaluate outcomes in long-COVID-19 and post-COVID survivors
}

\author{
Anna Crispo ${ }^{1}$, Sabrina Bimonte $2^{*} \mathbb{D}$, Giuseppe Porciello ${ }^{1}$, Cira Antonietta Forte ${ }^{2}$, Gaia Cuomo², \\ Concetta Montagnese ${ }^{1}$, Melania Prete ${ }^{1}$, Maria Grimaldi ${ }^{1}$, Egidio Celentano ${ }^{1}$, Alfonso Amore ${ }^{3}$, Elvio de Blasio ${ }^{4}$, \\ Francesca Pentimalli ${ }^{5}$, Antonio Giordano ${ }^{6,7}$, Gerardo Botti ${ }^{8}$, Giovanni Baglio ${ }^{9}$, Pierpaolo Sileri ${ }^{10}$, \\ Marco Cascella ${ }^{2}$ and Arturo Cuomo ${ }^{2}$
}

\begin{abstract}
SARS-CoV-2 infection can impact the physical, cognitive, mental health of patients, especially in those recovered in intensive care units. Moreover, it was proved that the effects of the virus may persist for weeks or months. The term long-COVID or post-COVID syndrome is commonly used for indicating a variety of physical and psychological symptoms that continue after the resolution of the acute phase. This narrative review is aimed at providing an updated overview of the impact of physical, cognitive, and psychological health disorders in COVID-19 survivors, by summarizing the data already published in literature in the last year. Studies cited were found through PubMed searches. We also presented an overview of the post-COVID-19 health consequences on three important aspects: nutritional status, neurological disorders, and physical health. Moreover, to activate a correct health planning policy, a multidisciplinary approach for addressing the post- COVID-19 issue, has been proposed. Finally, the involvement of health professionals is necessary even after the pandemic, to reduce expected post-pandemic psychosocial responses and mental health disorders.
\end{abstract}

Keywords: COVID-19 pandemic, Public health, Neurocognitive disorders, Intensive care units

\section{Introduction}

Clinical manifestations of COVID-19 vary from asymptomatic forms to self-limiting conditions, up to severe manifestations featuring respiratory and multi-organ involvement [1-6]. Epidemiological data reveal that up to $20 \%$ of COVID-19 patients progress to a severe condition that requires hospitalization [7]. Among those who are hospitalized, up to one-quarter need intensive care unit (ICU) admission, making them more vulnerable to secondary pneumonia, cardiac injury, sepsis, kidney injury, and neurologic disorders [8].

*Correspondence: s.bimonte@istitutotumori.na.it

${ }^{2}$ Division of Anesthesia and Pain Medicine, Istituto Nazionale dei Tumori Fondazione G. Pascale, 80131 Naples, Italy

Full list of author information is available at the end of the article
The term 'Long COVID' or 'Post-COVID' is commonly used to describe an array of signs and symptoms that are present after acute COVID-19. The UK's National Institute for Health and Care Excellence described the Long COVID as "ongoing symptomatic COVID-19" (symptoms between 4 and 12 weeks) and "Post-COVID syndrome" when symptoms lasting longer than 12 weeks [9]. Recently the Long COVID has been recognized by the World Health Organization (WHO) as an international healthcare concern and an "emergency-use" ICD code has been issued [10]. The study of the long-term outcome of patients discharged from ICU revealed significant disabilities, collectively known as post-intensive care syndrome (PICS) [2], affecting physical, cognitive, and psychological health. PICS includes symptoms like generalized weakness, memory disturbances, poor original author(s) and the source, provide a link to the Creative Commons licence, and indicate if changes were made. The images or other third party material in this article are included in the article's Creative Commons licence, unless indicated otherwise in a credit line to the material. If material is not included in the article's Creative Commons licence and your intended use is not permitted by statutory regulation or exceeds the permitted use, you will need to obtain permission directly from the copyright holder. To view a copy of this licence, visit http://creativecommons.org/licenses/by/4.0/. The Creative Commons Public Domain Dedication waiver (http://creativeco mmons.org/publicdomain/zero/1.0/) applies to the data made available in this article, unless otherwise stated in a credit line to the data. 
concentration, depression, anxiety, and post-traumatic distress disorder (PTSD) [2].

PICS incidence can be quite high: affecting up to $60 \%$ of the patients for what concerns cognitive and psychological symptoms and between 25 and $60 \%$ for what concerns neuromuscular disorders [11-13]. Furthermore, the PICS can last many years, affecting the health-related quality of life (HR-QoL) and the ability to return to work [14, 15]. Patients who survive acute distress respiratory syndrome (ARDS) could develop chronic pain and it would be possible that patients with a severe type of COVID-19 disease could develop similar complications [16]. Moreover, the psychological burden of ICU admission and stay of a patient can affect also his/her relatives who can develop symptoms of PTSD as well [17].

Here, we reviewed the clinical studies on neurocognitive disorders in Post-COVID patients. Studies cited in this narrative review were discovered through PubMed searches. PubMed was searched for clinical articles published in the last two years related to neurocognitive disorders, covid-19 survivors, physical cognitive, and mental health disorders. Based on these data, we proposed an overview of the COVID-19 health consequences by focusing on three important aspects: neurological disorders, physical health, and nutritional status.

\section{The post-COVID syndrome}

The Post-COVID Syndrome includes persistent symptoms related to residual inflammation, organ damage, non-specific effects from the hospitalization post-intensive care syndrome, social isolation, or impact on preexisting health conditions [18-20].

Post-COVID syndrome could be due to various mechanisms such as post-ICU syndrome, post-viral fatigue syndrome, permanent organ damage, or others [21]. Even if Long COVID was initially thought to be limited to survivors of hospital care and to those admitted to the ICU, it is now evident that most cases are described even in those who were not hospitalized or who did not immediately seek medical care [22-24].

The most frequent alterations include headache, dizziness, balance and coordination disorders, difficulty in attention, concentration, and memory, as well as chronic fatigue, insomnia, changes in taste and smell, depression, and anxiety. These physical, psychological, and neurocognitive symptoms are close to those present in post-traumatic stress disorder (PTSD) [25, 26].

Several studies observed persistent symptoms and unexpected substantial organ dysfunction after SARSCoV-2 infection in an increasing number of patients after recovering from their initial illness [27-29].

Data from a prospective cohort study on 270 COVID19 survivors confirmed a post-COVID-19 syndrome in half of the patients experiencing symptoms such as fatigue and respiratory (dyspnea) or neurological complaints, 10-14 weeks after disease onset [30,31] showed that $76 \%$ of hospitalized COVID-19 survivors reported at least one symptom that persisted, with fatigue or muscle weakness being the most frequently reported symptom, 6 months after illness onset.

Among ICU COVID-19 survivors several patients face impairments regarding their cognitive and mental health or physical function far beyond their hospital discharge [32].

Data from a UK study on the post-discharge impact of COVID-19 infection on the health status of 100 survivors (32 ICU) revealed that: fatigue was the most common reported symptom in both ICU COVID-19 survivors (72\%) and COVID-19 survivors (60\%), followed by breathlessness (66\% and $43 \%$, respectively) and psychological distress ( $47 \%$ and $24 \%$, respectively). Moreover, data showed a clinically significant HR-QoL in both ICU COVID-19 survivors (69\%) and COVID-19 survivors (46\%). Sixty percent of the ICU COVID-19 survivors and $15 \%$ of the COVID-19 survivors remained off-sick from work after 4 weeks or more since discharge [29].

Data collected among symptomatic adults tested in outpatient settings (patients with mild COVID-19 without hospitalization) reported that $94 \%$ experienced one or more symptoms (cough $43 \%$, fatigue $35 \%$, or shortness of breath $29 \%$ ) after infection onset, resulting in prolonged illness [28]. Persistent symptoms (such as anosmia/ageusia, dyspnea, or asthenia) have been reported in twothirds of patients with non-critical COVID-19 [30]. The ongoing COVID-19 pandemic and the occurrence of Post-COVID syndrome has highlighted the PICS issue and the complex rehabilitation needs for people with severe illness and long ICU stays as well as for COVID19 survivors that have not been hospitalized. The persistence of various symptoms in Long-COVID patients is a major health issue worldwide. Monitoring and treatment of patients with post-COVID syndrome are necessary to ensure rehabilitation and recovery of general functions. These findings support the need for a multidisciplinary approach to the care of this vulnerable population and to conduct research studies during 1-2 years of follow-up, as is currently happening in the UK and USA $[31,33,34]$ (see Table 1).

\section{Potential tools to evaluate outcomes in long-COVID and post-COVID patients: our proposal}

Cognitive, physical, and psychological dysfunction reported by COVID19 patients can have profound effects on the HR-QoL [32].

We proposed a multimodal process as well as the sequence of several aspects of the health-related quality 


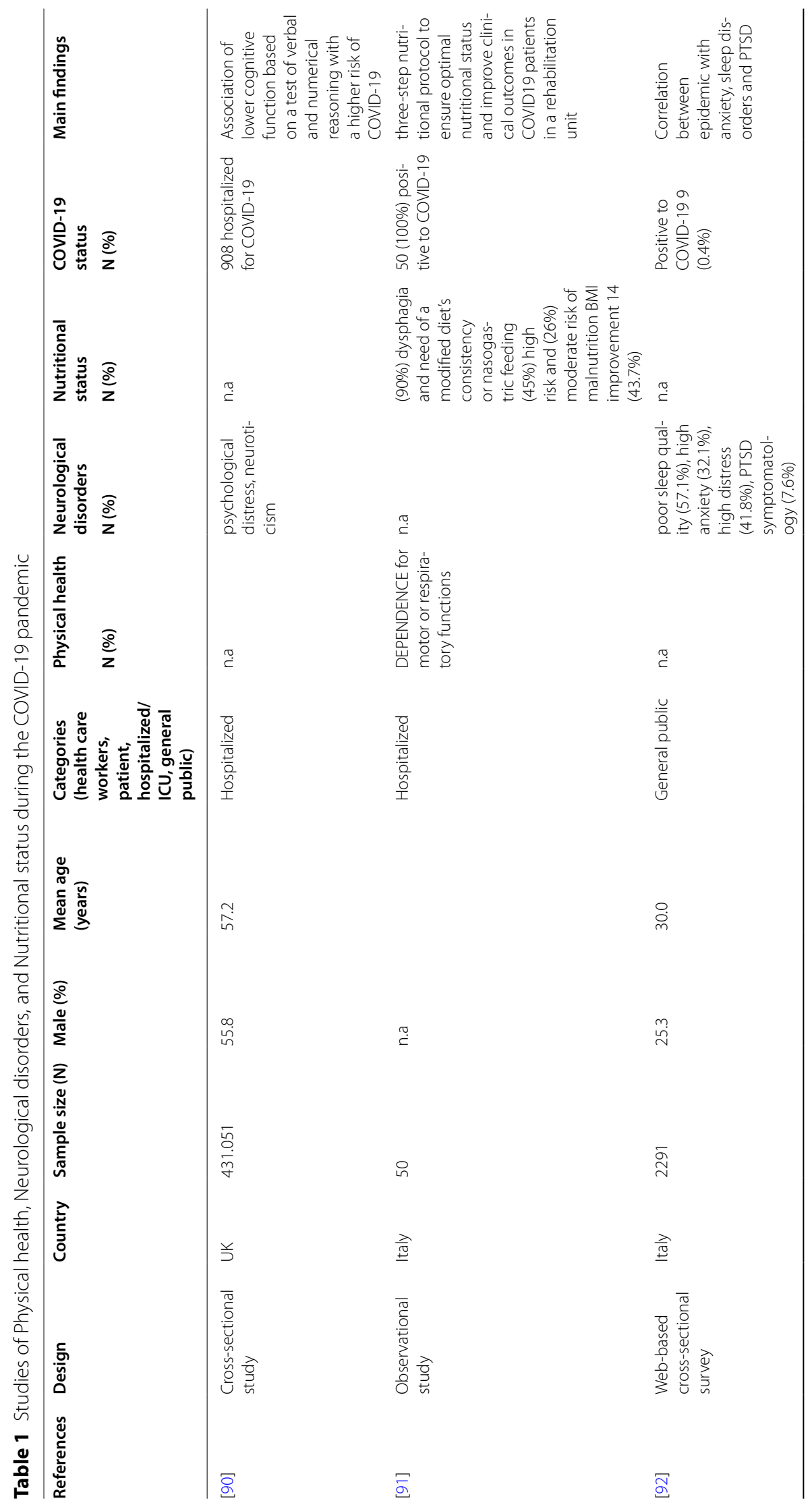




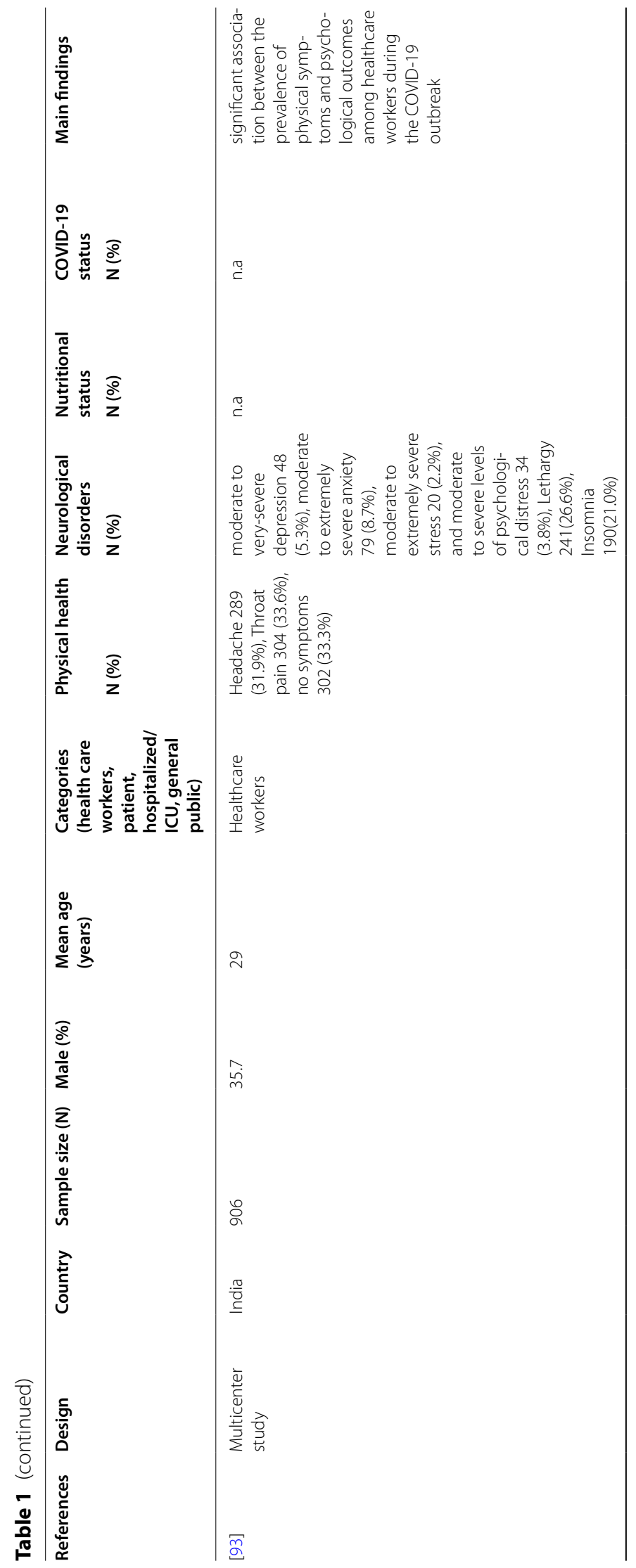




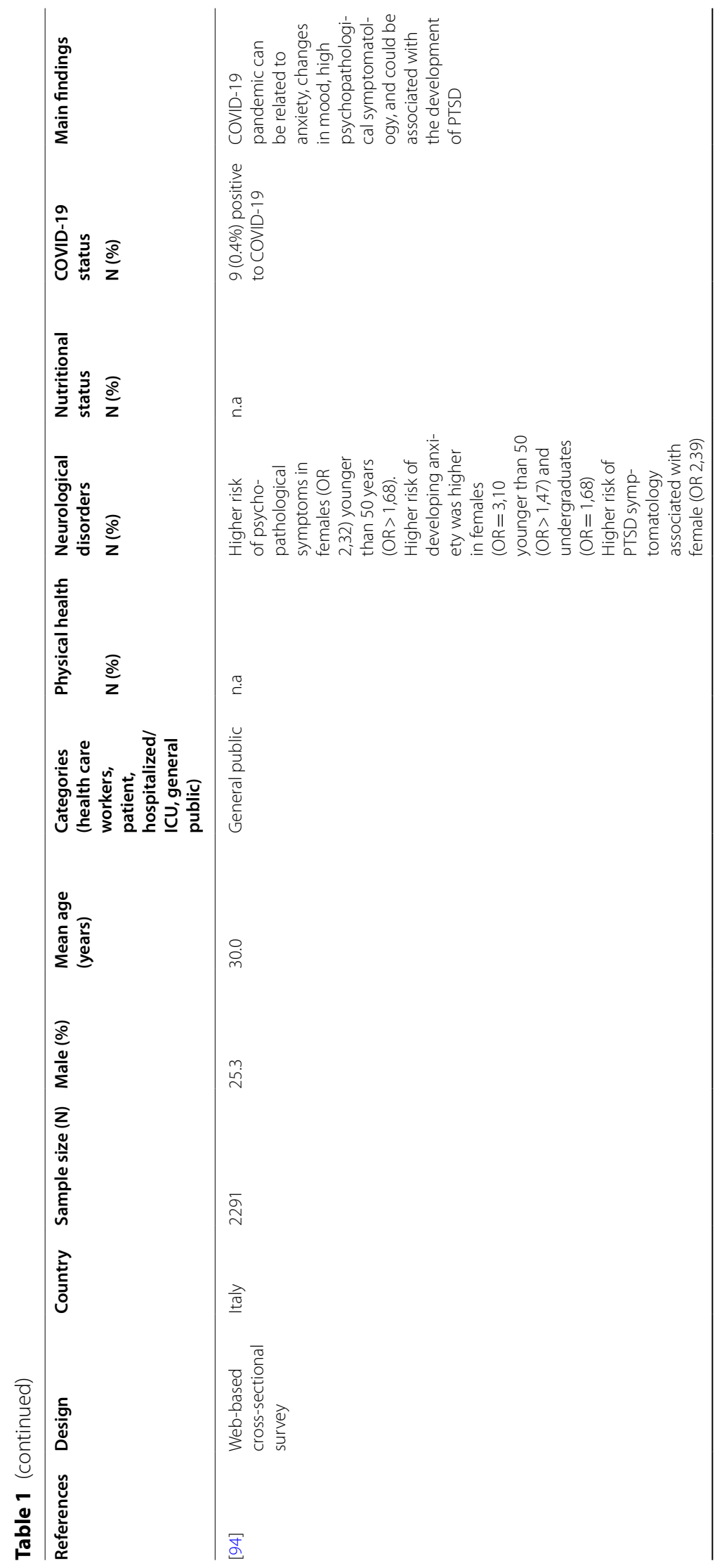




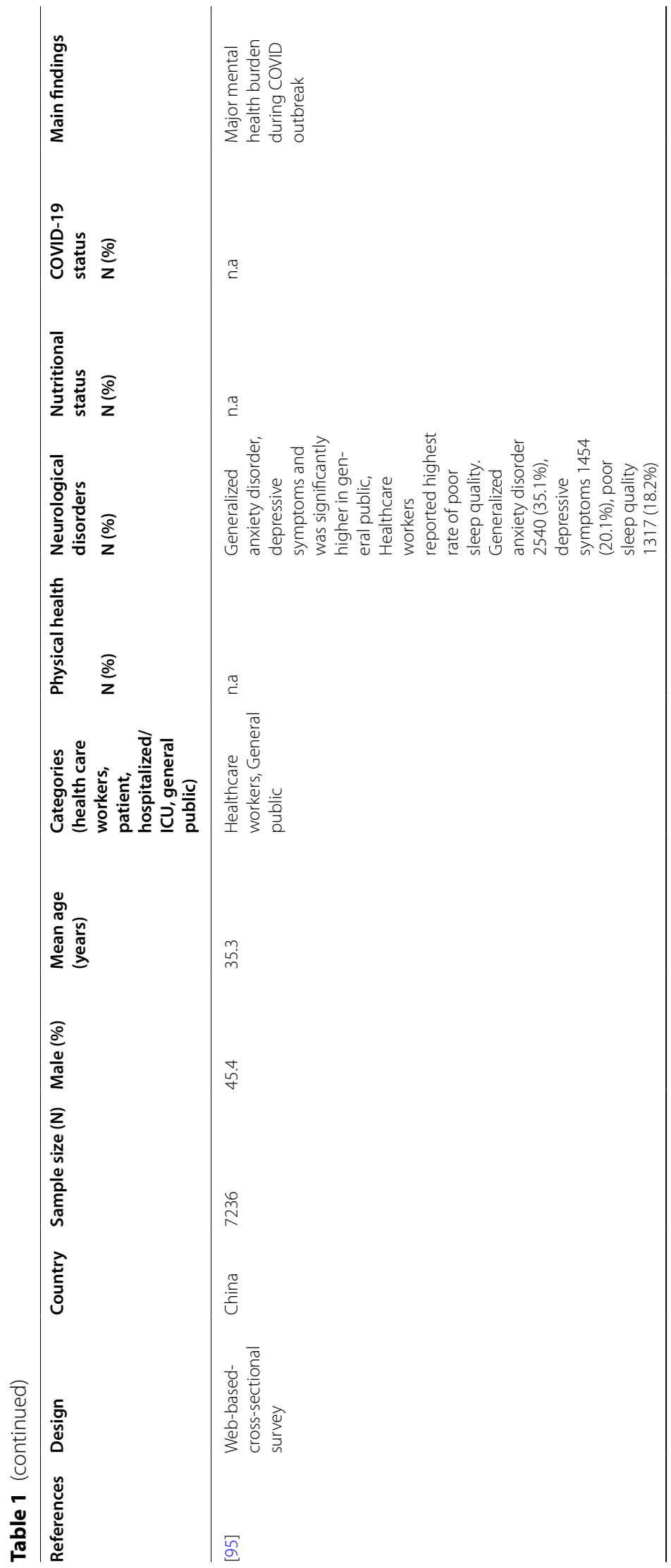




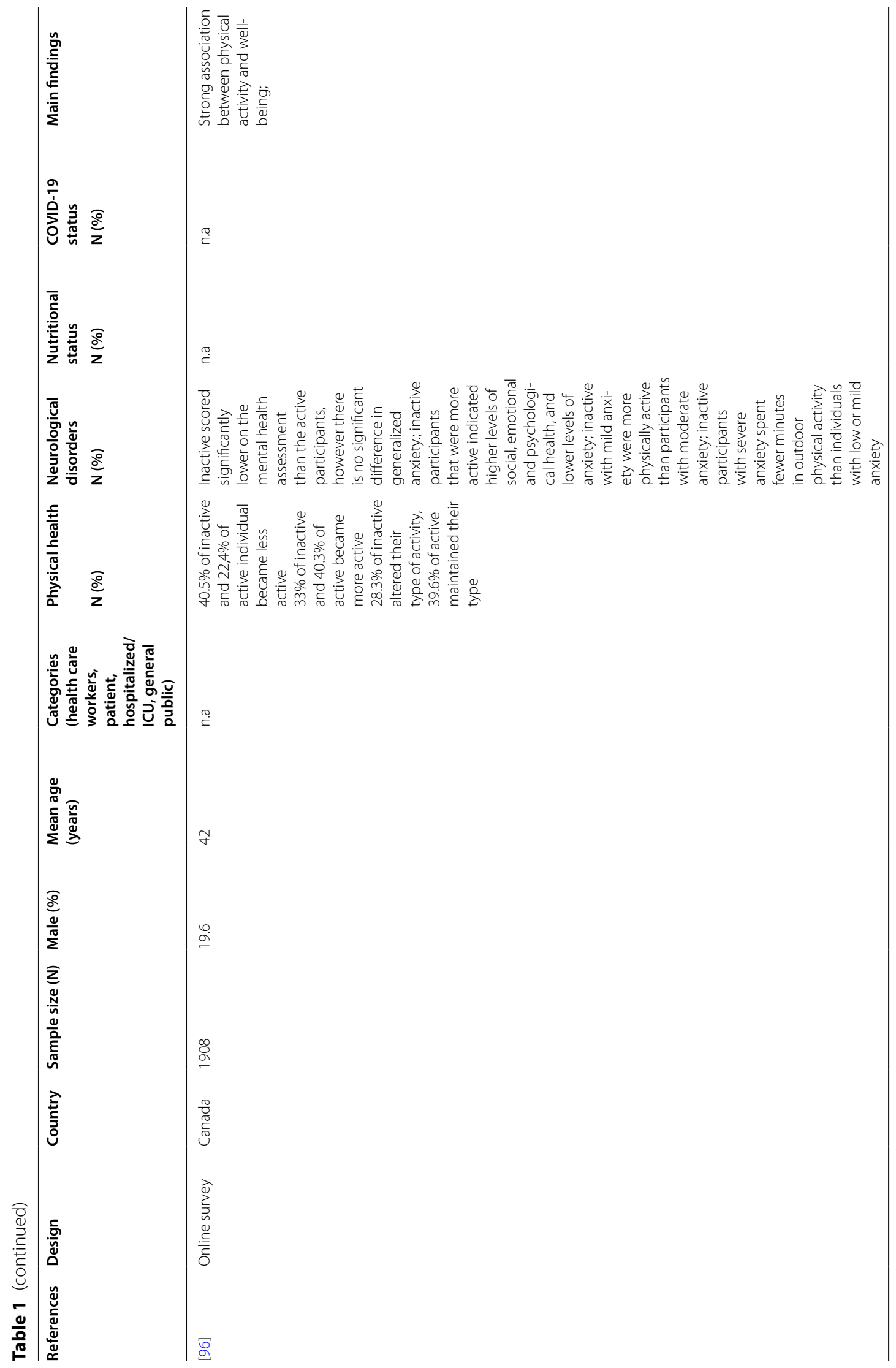




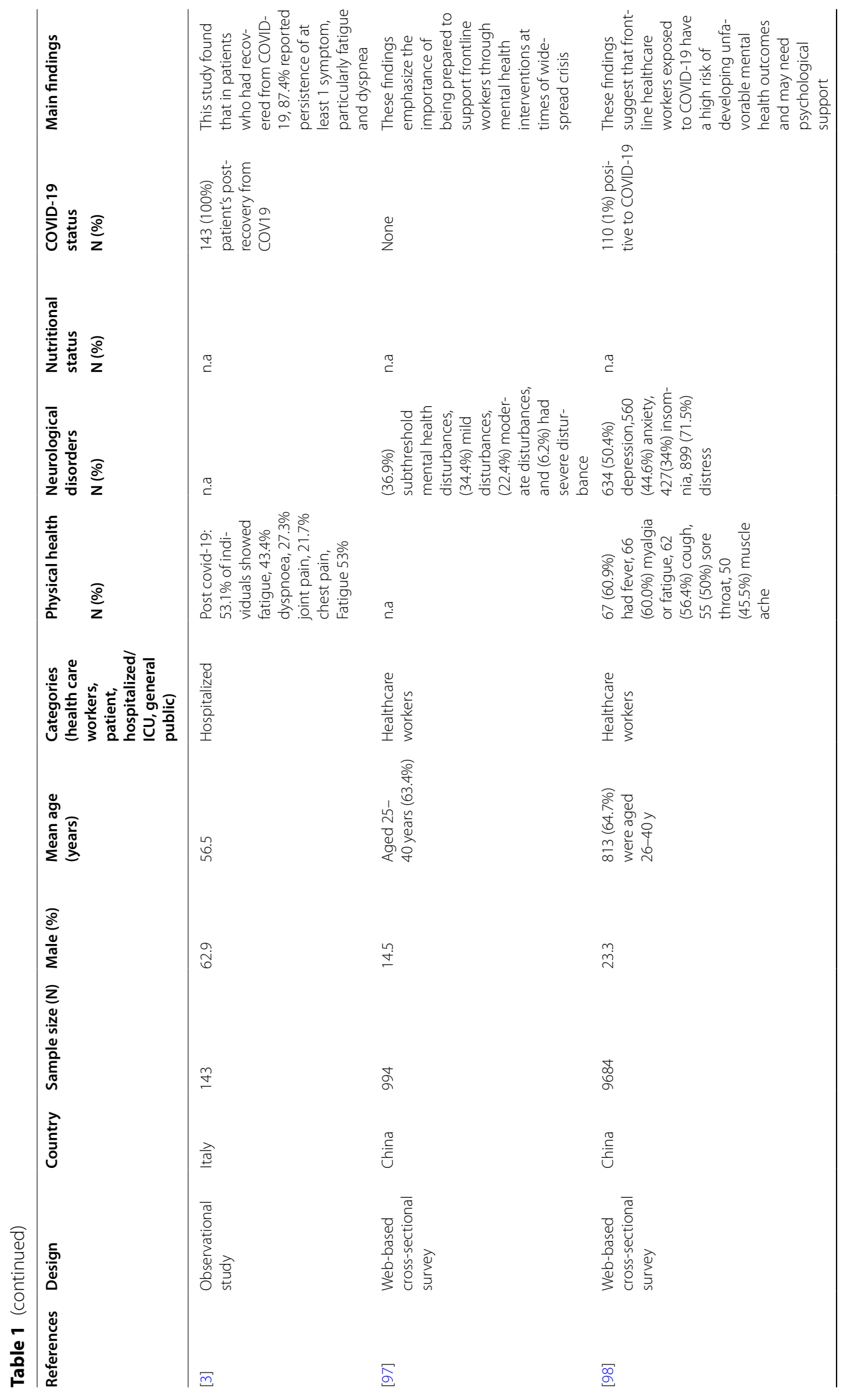




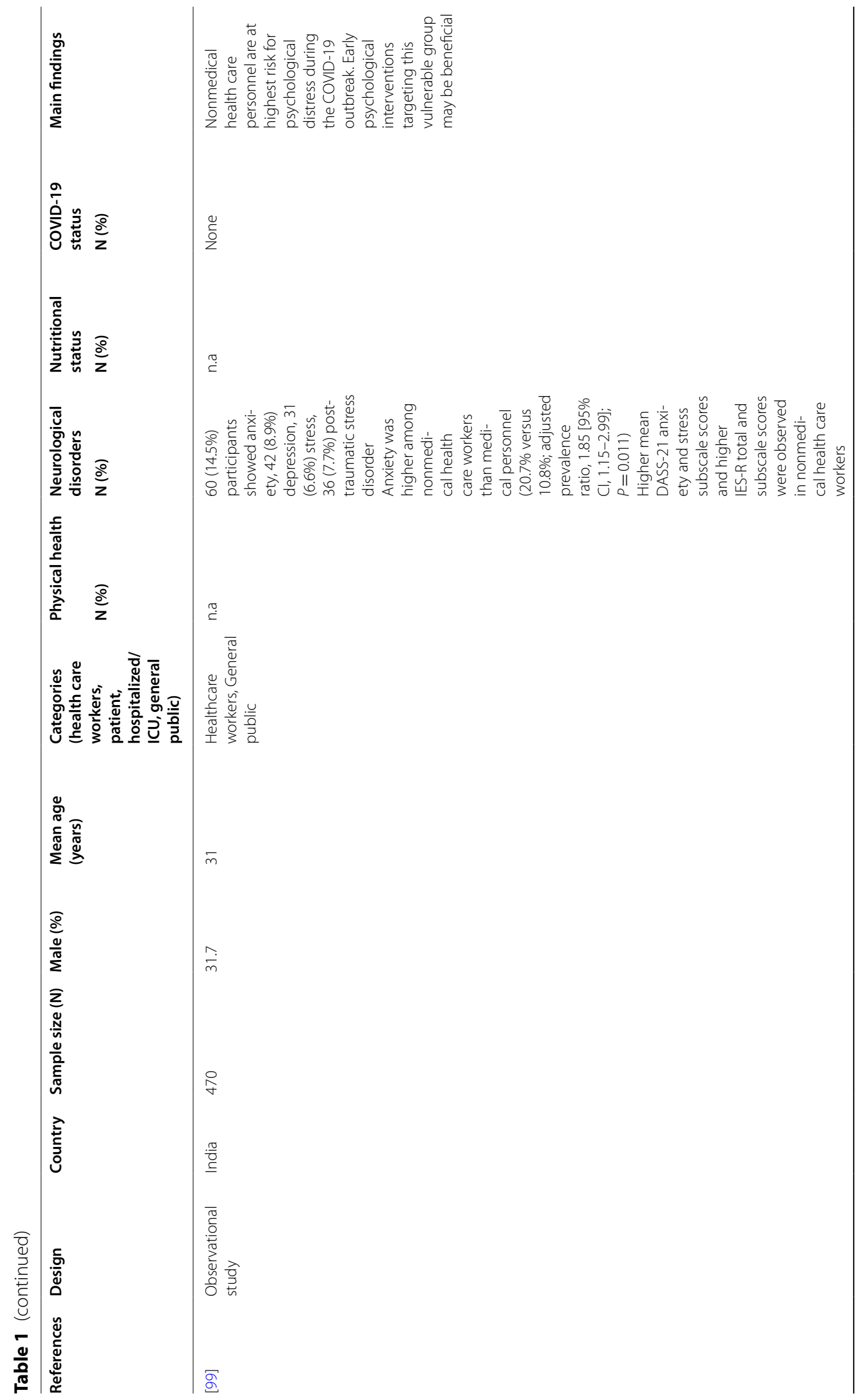




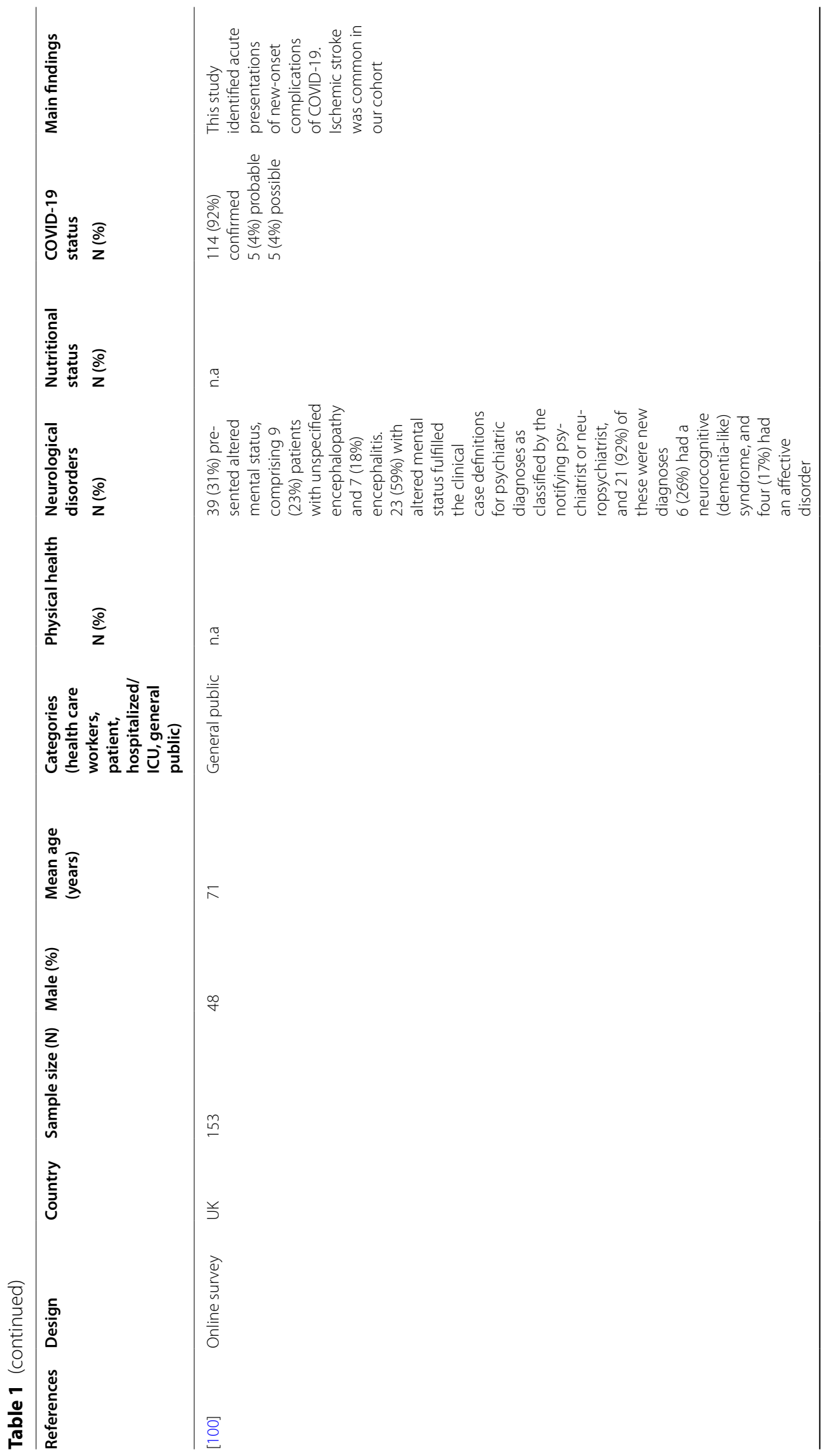




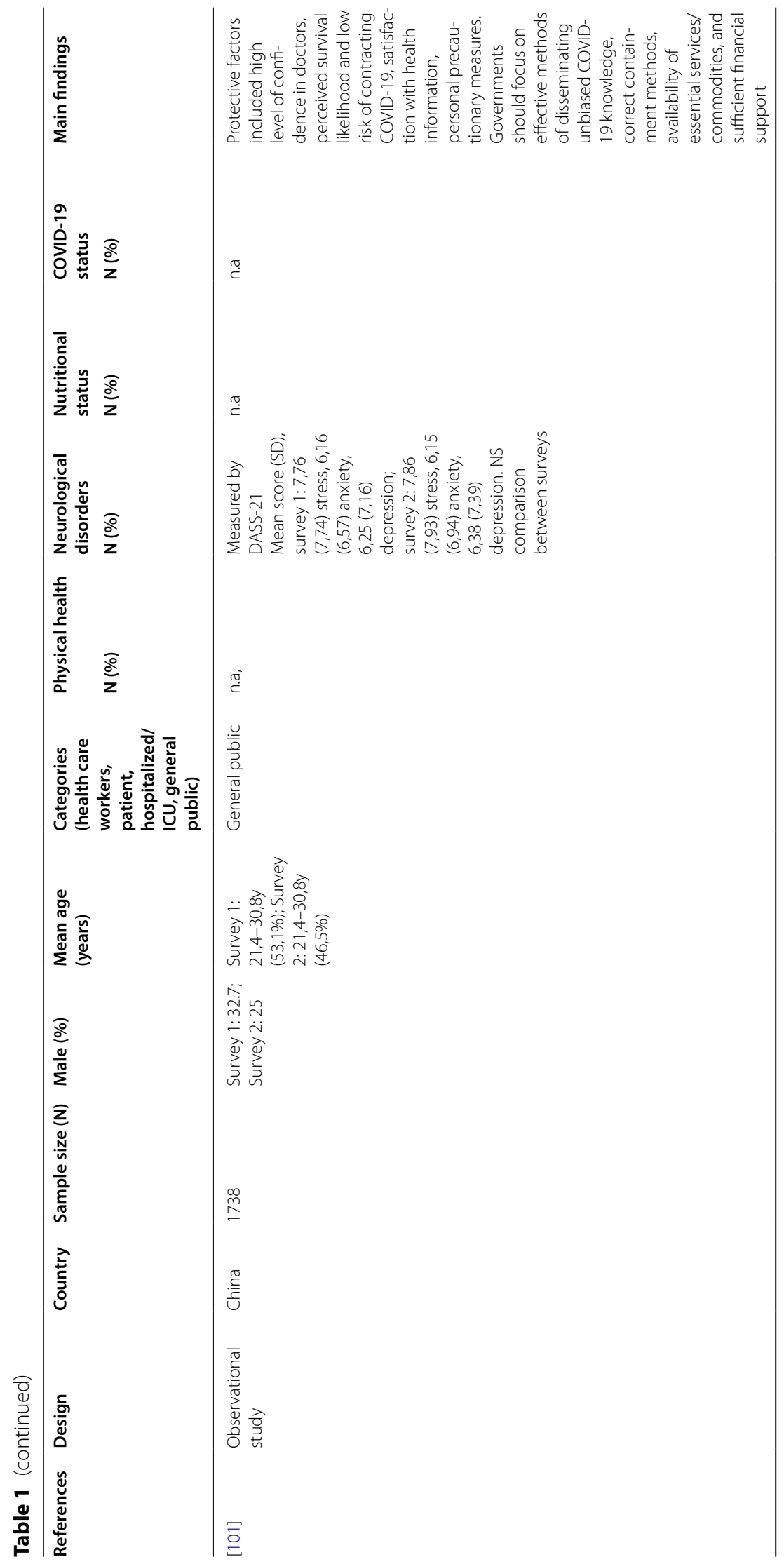




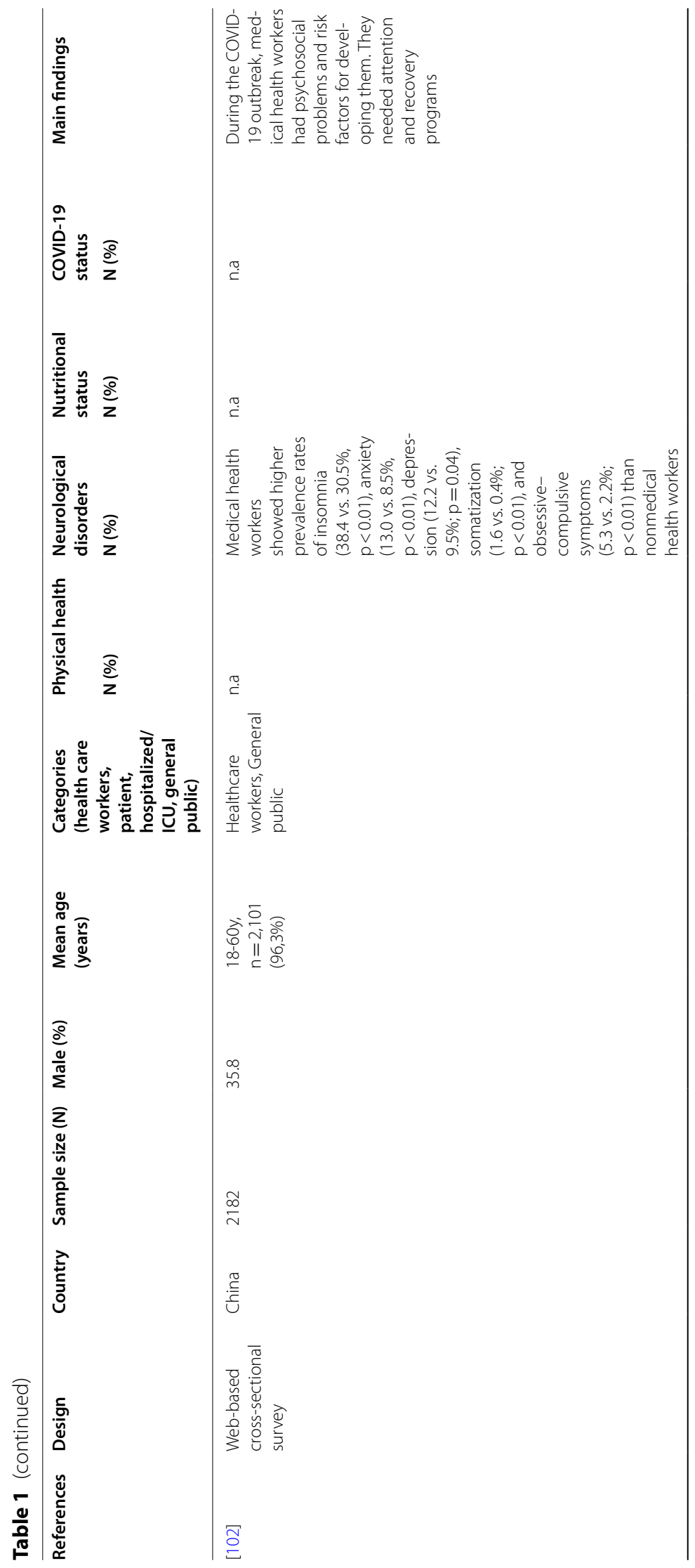




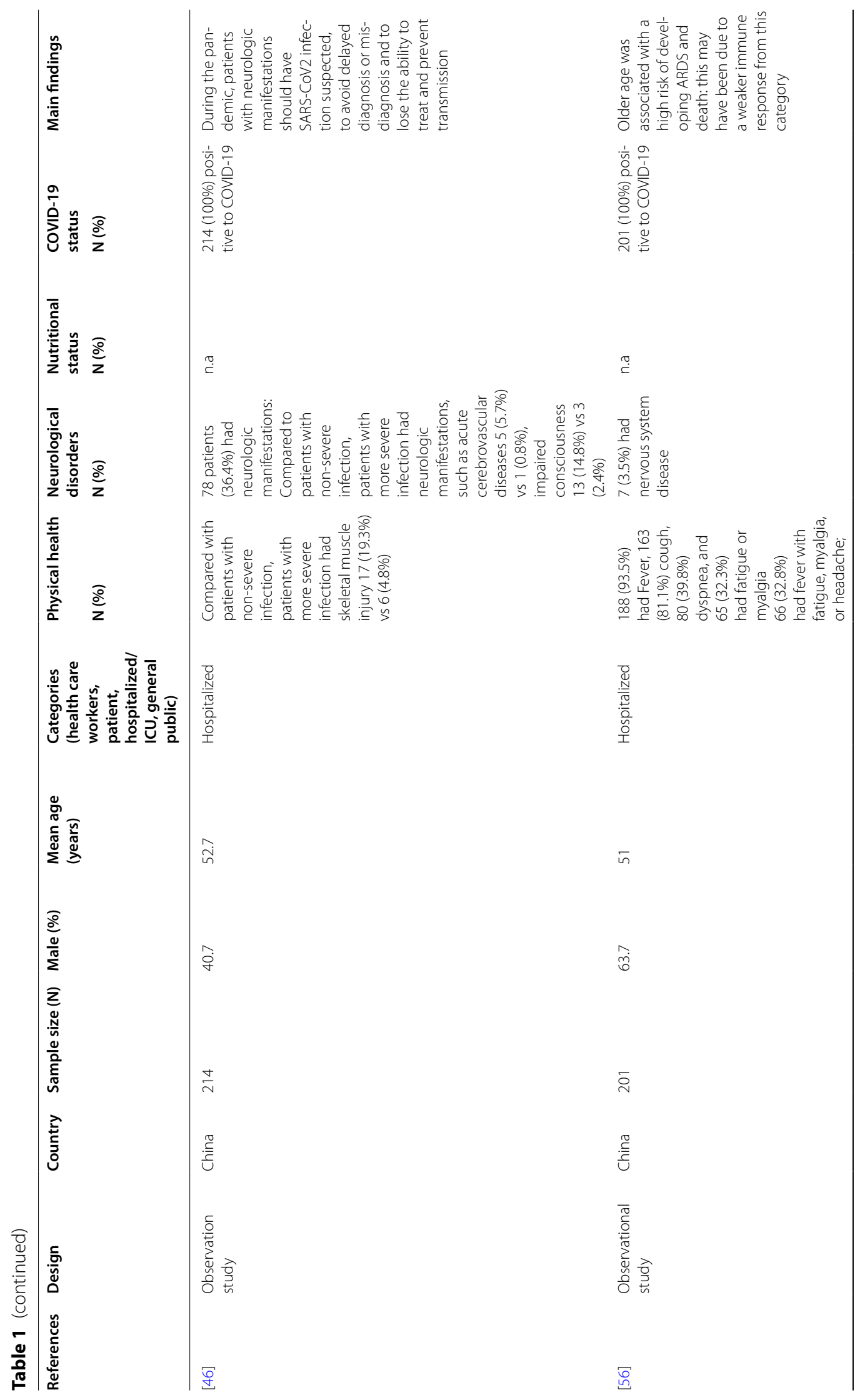




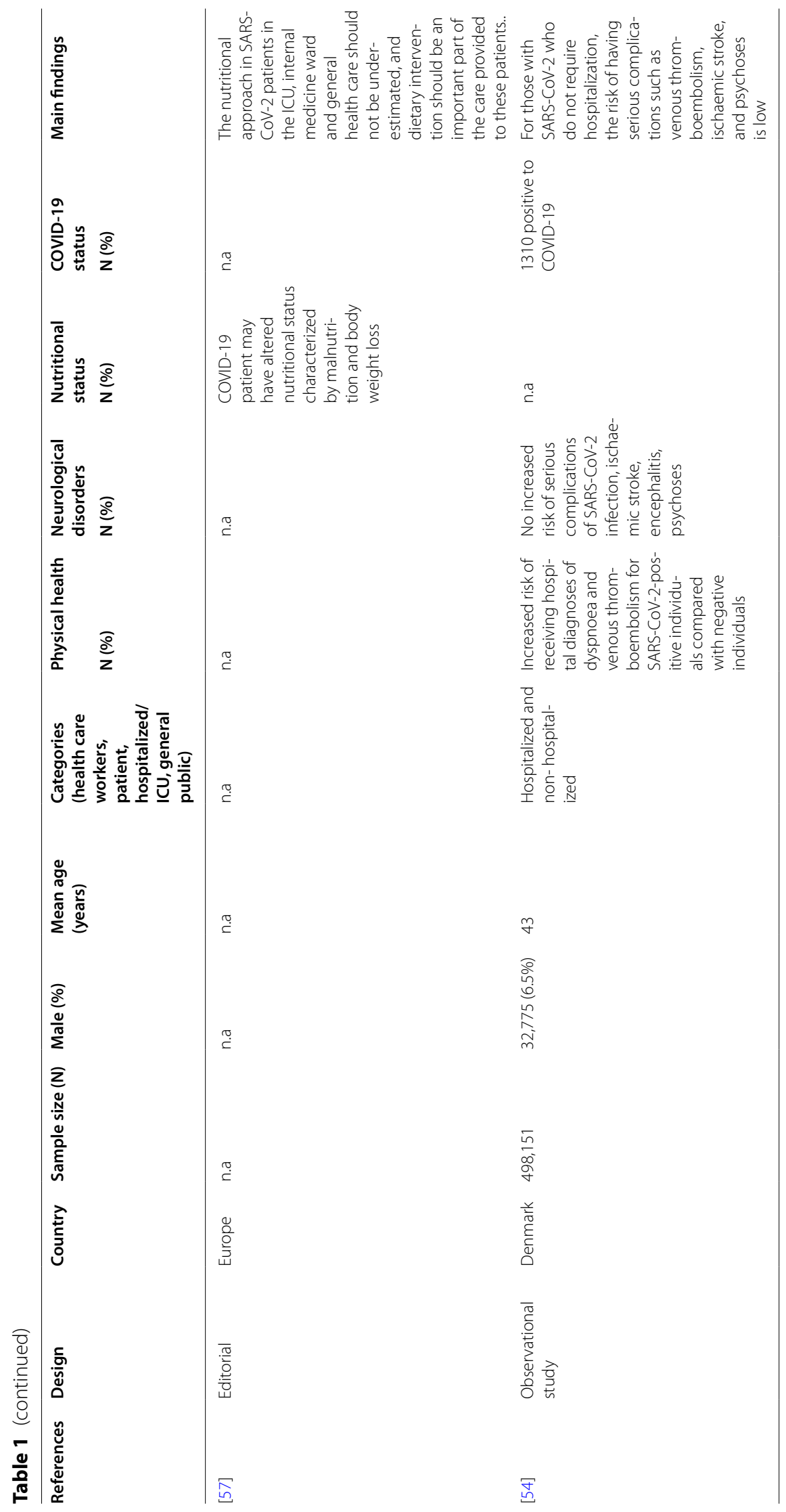


of life (HRQoL) contributing to the impact of the disease on cognitive, physical, and nutritional outcomes by considering the set of the following tools:

1. The Short Form Health Survey 36 (SF-36), which is a short questionnaire (36 items) that evaluates eight dimensions: physical functioning (10 items), social functioning (2 items), limitations due to physical problems (4 items), limitations due to emotional problems (3 items), mental health (5 items), energy/vitality (4 items), pain ( 2 items) and perception of general health (6 items) [35]. The SF-36 investigates the health changes of an individual compared to the previous year. As the tool evaluates the state of health in general, it is suitable for studies in the general population and transversal or longitudinal investigations on specific diseases, and treatments. Due to its characteristic of a general questionnaire, it needs to be accompanied by specific questionnaires when studying patient populations.

2. The Barthel Index, developed to measure improvements in individuals with a chronic disability who underwent rehabilitation programs, is commonly used in post-ARDS patients [36].

3. The Psychological General Well-Being Index (PGWBI) is designed for providing an index for measuring subjective well-being or suffering. It is composed of 22 items to assess anxiety, depression, positive well-being, self-control, general health, and vitality[37].

4. The EuroQoL [38]. It represents the attempt to develop a standardized, general tool for describing and evaluating HRQoL regardless of the specific disease. It is a questionnaire consisting of five dimensions and an analog self-assessment scale.

5. The Pittsburgh Sleep Quality Index (PSQI), for assessing sleep quality[39].

6. The Mini-Mental Test investigates the neurocognitive and functional state through simple targeted questions as well as small graphical tasks. It explores different domains of brain function, such as orientation, memory, attention and calculation, the ability to recall certain acquisitions, language, etc. [40].

7. The Brief Pain Inventory (BPI) rapidly assesses the severity of pain and its impact on functioning [41].

8. PTSS-14 (Post Traumatic Stress Syndrome 14 items) is a screening instrument to identify the patients who developed the Syndrome [42].

9. HADS (Hospital Anxiety and Depression Scale) to evaluate the level of depression and anxiety of the patients discharged at home [43].
10. MNA (Mini Nutritional Assessment) a nutritional educational program to assess nutritional status in patients in healthcare settings, appears ideal for patients with COVID -19, alongside a clinical and Para clinical evaluation $[44,45]$.

\section{Focus on three aspects to manage COVID-19 survivors}

We underline three important aspects to manage COVID-19 survivors: (1) neurological disorders, (2) physical health, (3) nutritional status.

(1) Neurological disorders

Accumulated pieces of evidence highlighted that SARS-CoV-2 affected the nervous system [46-48]. In patients with a severe form of the disease, neurological manifestations were more evident. As reported by Mao et al. [46], neurologic manifestations affected or the central nervous system (CNS) (dizziness, headache, impaired consciousness, acute cerebrovascular disease, ataxia, and seizure), or the peripheral nervous system (PNS) (nerve pain and impairment of vision, test, and smell) or the skeletal muscular apparatus (injury). Among CNS alterations, the acute cerebrovascular disease was more evident in older patients and with severe infection and included cerebral hemorrhage and ischemic stroke diagnosed by clinical symptoms and head CT. Carfi et al. [3] demonstrated that worsened quality of life was observed in $44.1 \%$ of patients, and $87.4 \%$ reported persistence of at least 1 symptom, particularly fatigue and dyspnoea. The pathologic mechanism underlying the CNS invasion of SARS-CoV-2 is presumably like that of other respiratory viruses. Specifically, SARS-COV-2 can invade the CNS through the hematogenous or retrograde neuronal route. Since SARS-CoV-2 infects a large part of the world's population, understanding the potential neurologic implications of COVID-19 will help clinicians to identify and intervene in neurologic morbidity during and after the pandemic.

(2) Physical health

Patients who have undergone intensive care after discharge may experience a post-intensive care syndrome (PICS) characterized by physical, mental, cognitive [1], and nutritional problems [49]. The impact of ICU on physical function can impair daily activities, involving the neuromuscular, cardio-respiratory, and skeletal systems: these individuals very often report inability to return to work, musculoskeletal weakness and difficulty walking, impaired lung and respiratory function [50-53].

Most of the complications due to COVID-19 described were related to hospitalized patients and therefore not associated with patients who received home care. Few studies have evaluated the presence of complications in patients positive for SARS-Cov-2 who did not require 


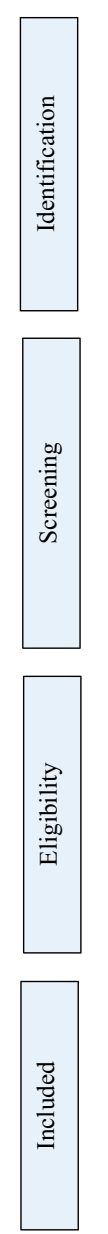

$$
\begin{gathered}
\begin{array}{c}
\text { Records identified through } \\
\text { database searching }(\mathrm{n}=4212)
\end{array} \\
\text { - } \quad \text { Pubmed }(\mathrm{n}=3570) \\
\text { - } \quad \text { Embase }(\mathrm{n}=316) \\
\text { - } \quad \text { Scopus }(\mathrm{n}=326)
\end{gathered}
$$

Additional records identified

through reference lists $(\mathrm{n}=0)$
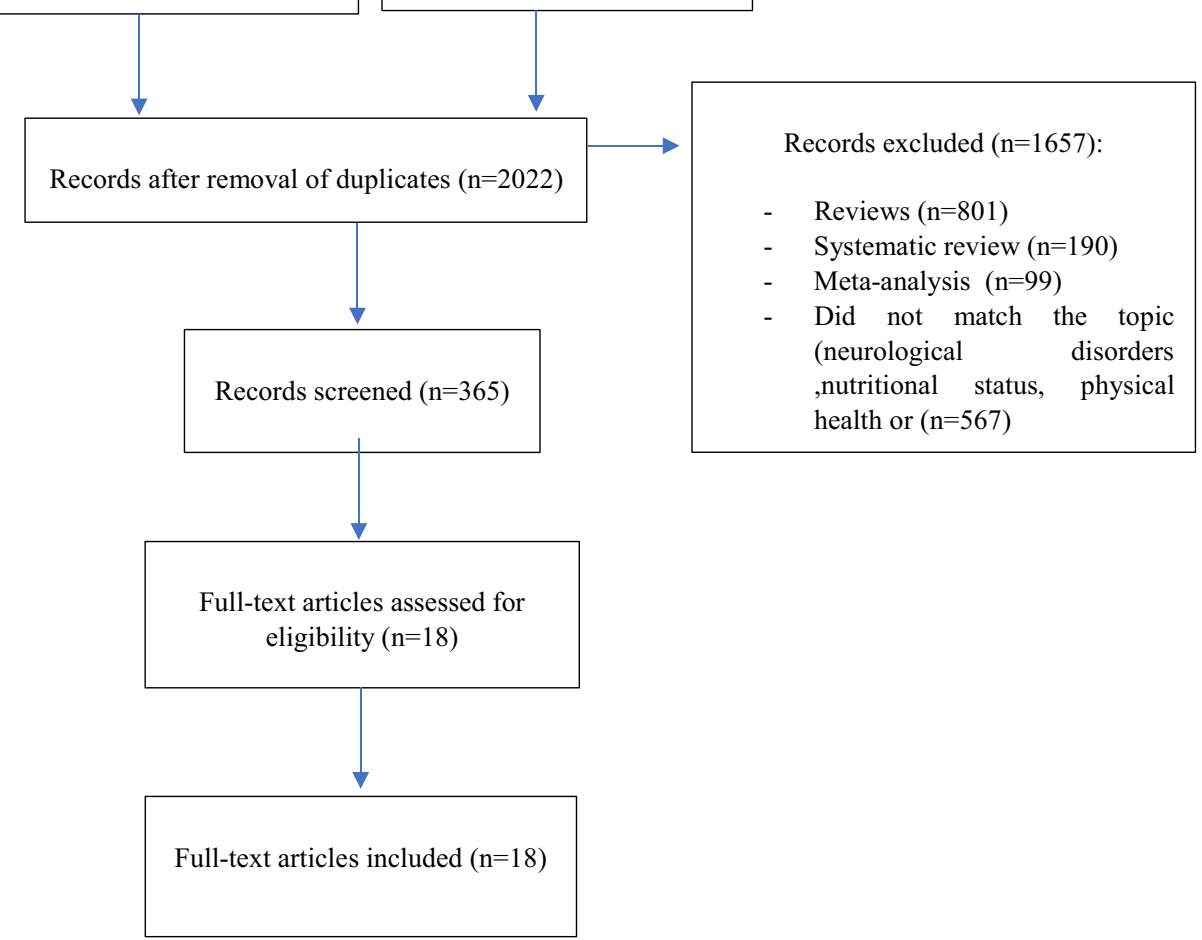

Fig. 1 PRISMA flow diagram

hospital care but were still positive for SARS-Cov-2. In a population-based cohort study in Denmark, it was found that the risk of severe complications after COVID19 in non-hospitalized patients about 6 months after the infection is very low, but these still have a higher risk for venous thrombotic events than people without disease and negative for SARS-Cov-2 [54]. There are currently no other studies evaluating the long-term effects of the virus in non-hospitalized patients beyond six months of infection.

(3) Nutritional status

Previous studies have highlighted the poor nutritional status of patients upon admission and during their stay in intensive care. The greater propensity for malnutrition and wasting is more visible in these critically ill patients, due to their developed metabolic disorders [49]. Nutritional status has long been considered an important factor that can influence the outcome of various infectious diseases, including viral pneumonia caused by SARSCoV2 (COVID-19) [55, 56]. In COVID-19 patients, an altered nutritional status characterized by malnutrition and loss of body weight can be found and due to various causes $[57,58]$, including dyspnoea, anorexia, dysphagia, nausea, vomiting, diarrhea, increased energy requirements [59] advanced age, frailty, comorbidity [57] and prolonged hospital stay in ICU [58]. Currently, there are no specific dietary guidelines for post-COVID-19 patients with PICS disorders. However, several aspects could be considered to improve the impairments of cognitive functions. Eating habits can affect cognitive abilities [60]: unbalanced diets can have an overall negative impact on cognitive and mental health [61-63], negatively affecting the ability to reason, attention, and memory $[61,62,64]$ and promote dementia and depression [65-68]. Greater adherence to a diet that includes healthy foods such as vegetables, fruits, seafood, lean meats, and whole grains, reduces the likelihood of suffering from depression or anxiety [69-71]. Nutrients such as vitamins (B1, B6, B12, B9, C, E, D), polyphenols, $\omega-3$ fatty acids, minerals (iron, zinc, selenium), and foods with a 
low glycemic index have inhibitory action against oxidative stress and neuroinflammation [72, 73], and positively influence cognitive function [68, 74-84]. In this regard, several studies have reported that greater adherence to the Mediterranean diet was associated with an improvement in cognitive function and a reduced risk of cognitive impairment [83, 85-89]. It would be useful to monitor body composition, using methods such as bio impedance-analysis (BIA) or plicometry, and the nutritional status using the MNA [44, 45], to offer the most adequate nutritional support that contributes to reduce physical and cognitive complications both in post-hospitalization and in the long term.

\section{Conclusions}

The Sars-Cov-2 is an invisible enemy that makes us feel constantly under threat, it can infect people at any time, and this can generate different responses in subjects: anxiety, depression, panic, sleep, concentration disorders, and fatigue. All normal and legitimate reactions, however, must be contained to try to limit the effects, allowing us to better face the emergency we are experiencing. COVID-19 survivors, after clinical recovery, may have neurocognitive damage that should not be underestimated, and the extent and duration of which is not yet known. As we reported, also the COVID-19 survivors (without hospitalization), reported the postCOVID-19 syndrome. The most frequent alterations found are headache, balance and coordination disorders, difficulty in attention, insomnia, changes in taste and smell, depression, anxiety, physical and nutritional dysfunctions. The isolation, the hospitalization, the drama of the health emergency could have been decisive in the onset of some of these symptoms. Overall, the impact of post- COVID-19 syndrome should be considered as the potential cause of a delayed pandemic that may have a major public health impact in the medium to long term. Thus, preventive interventional approaches mitigating social impact should be considered as an integral part of the response to the crisis during pandemics. Moreover, the involvement of specific health professional figures is needed even after the pandemic, to manage and care for an increased number of patients (Fig. 1).

\footnotetext{
Abbreviations

PICS: Post-intensive care syndrome; ICUs: Intensive care units; PTSD: Posttraumatic distress disorder; ARDS: Acute respiratory distress syndrome; HRQOL: Health-related quality of life; SF-36: Short Form Health Survey 36; PGWBI: The Psychological General Well-Being Index; PSQI:The Pittsburgh Sleep Quality Index; BPI: Brief Pain Inventory; PTSS-14: Post Traumatic Stress Syndrome 14 items; HADS: Hospital Anxiety and Depression Scale; MNA: Mini Nutritional Assessment; BIA: Bio impedance-analysis.
}

\section{Acknowledgements}

The authors are grateful to Alessandra Trocino and Mrs. Maria Cristina Romano from the National Cancer Institute of Naples for providing excellent bibliographic service and assistance.

\section{Authors' contributions}

The present review was mainly written by AC and SB. All authors contributed toward data analysis, drafting, and critically revising the paper, gave final approval of the version to be published, and agree to be accountable for all aspects of the work. All authors read and approved the final manuscript.

\section{Availability of data and materials}

Data sharing not applicable to this article as no datasets were generated or analyzed during the current study.

\section{Declarations}

Ethics approval and consent to participate Not applicable.

\section{Consent for publication}

Not applicable.

\section{Competing interests}

The authors declare that they have no competing interests.

\section{Author details}

${ }^{1}$ Epidemiology and Biostatistics Unit, Istituto Nazionale Tumori-IRCCS-Fondazione G. Pascale, 80131 Naples, Italy. ${ }^{2}$ Division of Anesthesia and Pain Medicine, Istituto Nazionale dei Tumori Fondazione G. Pascale, 80131 Naples, Italy. ${ }^{3}$ SSD Chirurgia Melanoma E Dei Tumori Cutanei, Istituto Nazionale Tumori-IRCCSFondazione G. Pascale, 80131 Naples, Italy. ${ }^{4}$ Multidisciplinary Emergency Unit for COVID-19 Campania, 80100 Naples, Italy. ${ }^{5}$ Cell Biology and Biotherapy Unit, Istituto Nazionale Tumori-IRCCS-Fondazione G. Pascale, 80131 Naples, Italy. ${ }^{6}$ Ministry of Health, 00153 Rome, Italy. ${ }^{7}$ Center for Biotechnology, College of Science and Technology, Sbarro Institute for Cancer Research and Molecular Medicine, Temple University, Philadelphia, PA 19122, USA. ${ }^{8}$ Scientific Direction, Istituto Nazionale Tumori IRCCS Fondazione G. Pascale, Naples, Italy. ${ }^{9} \mathrm{Head}$ of the Unit "Research and International Relations", Italian National Agency for Regional Health Services - AGENAS, 00187 Rome, Italy. ${ }^{10}$ Università Vita Salute San Raffaele, 20132 Milan, Italy.

Received: 16 March 2021 Accepted: 15 October 2021

Published online: 30 October 2021

\section{References}

1. Azoulay E, Vincent JL, Angus DC, Arabi YM, Brochard L, Brett SJ, Citerio G, Cook DJ, Curtis JR, Dos Santos CC, et al. Recovery after critical illness: putting the puzzle together-a consensus of 29. Crit Care. 2017;21(1):296.

2. Rawal G, Yadav S, Kumar R. Post-intensive care syndrome: an overview. J Transl Intern Med. 2017;5(2):90-2.

3. Carfi A, Bernabei R, Landi F. Gemelli against C-P-ACSG: persistent symptoms in patients after acute COVID-19. JAMA. 2020;324(6):603-5.

4. Tanno LK, Casale T, Demoly P. Coronavirus disease (COVID)-19: world health organization definitions and coding to support the allergy community and health professionals. J Allergy Clin Immunol Pract. 2020;8(7):2144-8. https://doi.org/10.1016/j.jaip.2020.05.002.

5. Neufeld KJ, Leoutsakos JS, Yan H, Lin S, Zabinski JS, Dinglas VD, Hosey MM, Parker AM, Hopkins RO, Needham DM. Fatigue symptoms during the first year following ARDS. Chest. 2020;158(3):999-1007.

6. Khan MNM, Sarker MS. A review of coronavirus 2019 (Covid-19), a life threating disease all over the world. World Cancer Res J. 2020;7:e1586.

7. Sidiras G, Patsaki I, Karatzanos E, Dakoutrou M, Kouvarakos A, Mitsiou G, Routsi C, Stranjalis G, Nanas S, Gerovasili V. Long term follow-up of quality of life and functional ability in patients with ICU acquired weakness: a post hoc analysis. J Crit Care. 2019;53:223-30. 
8. Kamdar BB, Suri R, Suchyta MR, Digrande KF, Sherwood KD, Colantuoni E, Dinglas VD, Needham DM, Hopkins RO. Return to work after critical illness: a systematic review and meta-analysis. Thorax. 2020;75(1):17-27.

9. Griffiths J, Hatch RA, Bishop J, Morgan K, Jenkinson C, Cuthbertson $\mathrm{BH}$, Brett SJ. An exploration of social and economic outcome and associated health-related quality of life after critical illness in general intensive care unit survivors: a 12-month follow-up study. Crit Care. 2013;17(3):R100

10. Davidson JE, Jones C, Bienvenu OJ. Family response to critical illness: postintensive care syndrome-family. Crit Care Med. 2012;40(2):618-24.

11. Ely EW. The ABCDEF bundle: science and philosophy of how ICU liberation serves patients and families. Crit Care Med. 2017;45(2):321-30.

12. Haines KJ, Sevin CM, Hibbert E, Boehm LM, Aparanji K, Bakhru RN, Bastin AJ, Beesley SJ, Butcher BW, Drumright K, et al. Key mechanisms by which post-ICU activities can improve in-ICU care: results of the international THRIVE collaboratives. Intensive Care Med. 2019;45(7):939-47.

13. Chippa V, Aleem A, Anjum F. Post Acute Coronavirus (COVID-19) Syndrome. [Updated 2021 Oct 1]. In: StatPearls [Internet]. Treasure Island (FL): StatPearls Publishing; 2021. Available from: https://www.ncbi.nlm. nih.gov/books/NBK570608/.

14. Al-Jahdhami I, Al-Naamani K, Al-Mawali A. The post-acute COVID-19 syndrome (long COVID). Oman Med J. 2021;36(1):e220.

15. Nalbandian A, Sehgal K, Gupta A, Madhavan MV, McGroder C, Stevens JS, Cook JR, Nordvig AS, Shalev D, Sehrawat TS, et al. Post-acute COVID19 syndrome. Nat Med. 2021;27(4):601-15.

16. Vittori A, Lerman J, Cascella M, Gomez-Morad AD, Marchetti G, Marinangeli F, Picardo SG. COVID-19 pandemic acute respiratory distress syndrome survivors: pain after the storm? Anesth Analg. 2020;131(1):117-9.

17. Meagher T. Long COVID: an early perspective. J Insur Med. 2021:49(1):19-23.

18. Carta MG, Orru G, Scano A, Coghe F, Nunnari G, Facchini G, Numis FG, Berretta M. In the face of the SARS-CoV-2 outbreak, do people suffering from oncological disease need specific attention? Eur Rev Med Pharmacol Sci. 2020;24(7):3434-6.

19. Hayes JP, Vanelzakker MB, Shin LM. Emotion and cognition interactions in PTSD: a review of neurocognitive and neuroimaging studies. Front Integr Neurosci. 2012;6:89.

20. Sudre CH, Murray B, Varsavsky T, Graham MS, Penfold RS, Bowyer RC, Pujol JC, Klaser K, Antonelli M, Canas LS, et al. Attributes and predictors of long COVID. Nat Med. 2021;27(4):626-31.

21. Cortinovis M, Perico N, Remuzzi G. Long-term follow-up of recovered patients with COVID-19. Lancet. 2021;397(10270):173-5.

22. Moreno-Perez $\mathrm{O}$, Merino E, Leon-Ramirez JM, Andres M, Ramos JM, Arenas-Jimenez J, Asensio S, Sanchez R, Ruiz-Torregrosa P, Galan I, et al. Post-acute COVID-19 syndrome. Incidence and risk factors: a Mediterranean cohort study. J Infect. 2021;82(3):378-83.

23. Ayoubkhani D, Khunti K, Nafilyan V, Maddox T, Humberstone B, Diamond I, Banerjee A. Post-COVID syndrome in individuals admitted to hospital with covid-19: retrospective cohort study. BMJ. 2021;372:n693.

24. Iwu CJ, Iwu CD, Wiysonge CS. The occurrence of long COVID: a rapid review. Pan Afr Med J. 2021;38:65.

25. Huang C, Huang L, Wang Y, Li X, Ren L, Gu X, Kang L, Guo L, Liu M, Zhou $X$, et al. 6-month consequences of COVID-19 in patients discharged from hospital: a cohort study. Lancet. 2021;397(10270):220-32.

26. Dönmez E, Temiz G, Dulger Z, Bayram Z, Doger BNB, Acar O, Demirci NS. The effects of Covid-19 phobia on quality of life: a cross-sectional study of cancer patients. World Cancer Res J. 2021;8:e1965. https://doi.org/10. 32113/wcrj_20215_1965.

27. Marra A, Pandharipande PP, Girard TD, Patel MB, Hughes CG, Jackson JC, Thompson JL, Chandrasekhar R, Ely EW, Brummel NE. Co-occurrence of post-intensive care syndrome problems among 406 survivors of critical illness. Crit Care Med. 2018;46(9):1393-401.

28. Tenforde MW, Kim SS, Lindsell CJ, Billig Rose E, Shapiro NI, Files DC, Gibbs KW, Erickson HL, Steingrub JS, Smithline HA, et al. Symptom duration and risk factors for delayed return to usual health among outpatients with COVID-19 in a multistate health care systems network: United States, March-June 2020. MMWR Morb Mortal Wkly Rep. 2020;69(30):993-8.

29. Halpin SJ, Mclvor C, Whyatt G, Adams A, Harvey O, McLean L, Walshaw C, Kemp S, Corrado J, Singh R, et al. Postdischarge symptoms and rehabilitation needs in survivors of COVID-19 infection: a cross-sectional evaluation. J Med Virol. 2021;93(2):1013-22.

30. Carvalho-Schneider C, Laurent E, Lemaignen A, Beaufils E, BourbaoTournois C, Laribi S, Flament T, Ferreira-Maldent N, Bruyere F, Stefic K, et al. Follow-up of adults with noncritical COVID-19 two months after symptom onset. Clin Microbiol Infect Off Publ Eur Soc Clin Microbiol Infect Dis. 2021;27(2):258-63.

31. Marshall M. The lasting misery of coronavirus long-haulers. Nature. 2020:585(7825):339-41.

32. Wu C, Cheng J, Zou J, Duan L, Campbell JE. Health-related quality of life of hospitalized COVID-19 survivors: an initial exploration in Nanning City, China. Soc Sci Med. 2021;274:113748.

33. Tirelli U, Taibi R, Chirumbolo S. Post COVID syndrome: a new challenge for medicine. Eur Rev Med Pharmacol Sci. 2021;25(12):4422-5.

34. Perrella A, Carannante N, Berretta M, Rinaldi M, Maturo N, Rinaldi L. Novel coronavirus 2019 (Sars-CoV2): a global emergency that needs new approaches? Eur Rev Med Pharmacol Sci. 2020;24(4):2162-4.

35. Brazier JE, Harper R, Jones NM, O'Cathain A, Thomas KJ, Usherwood T, Westlake L. Validating the SF-36 health survey questionnaire: new outcome measure for primary care. BMJ. 1992;305(6846):160-4.

36. Mahoney FI, Barthel DW. Functional evaluation: the Barthel Index. Md State Med J. 1965;14:61-5.

37. Grossi E, Groth N, Mosconi P, Cerutti R, Pace F, Compare A, Apolone G. Development and validation of the short version of the Psychological General Well-Being Index (PGWB-S). Health Qual Life Outcomes. 2006:4:88.

38. EuroQol G. EuroQol: a new facility for the measurement of healthrelated quality of life. Health Policy. 1990;16(3):199-208.

39. Buysse DJ, Reynolds CF 3rd, Monk TH, Berman SR, Kupfer DJ. The Pittsburgh Sleep Quality Index: a new instrument for psychiatric practice and research. Psychiatry Res. 1989;28(2):193-213.

40. Folstein MF, Folstein SE, McHugh PR. "Mini-mental state". A practical method for grading the cognitive state of patients for the clinician. J Psychiatr Res. 1975;12(3):189-98.

41. Caraceni A, Mendoza TR, Mencaglia E, Baratella C, Edwards K, Forjaz MJ, Martini C, Serlin RC, de Conno F, Cleeland CS. A validation study of an Italian version of the Brief Pain Inventory (Breve Questionario per la Valutazione del Dolore). Pain. 1996;65(1):87-92.

42. Parker AM, Nikayin S, Bienvenu OJ, Needham DM. Validity of the posttraumatic stress symptoms-14 instrument in acute respiratory failure survivors. Ann Am Thorac Soc. 2017;14(6):1047-8.

43. Zigmond AS, Snaith RP. The hospital anxiety and depression scale. Acta Psychiatr Scand. 1983;67(6):361-70.

44. Guigoz Y. The Mini Nutritional Assessment (MNA) review of the literature: what does it tell us? J Nutr Health Aging. 2006;10(6):466-85.

45. Haraj NE, El Aziz S, Chadli A, Dafir A, Mjabber A, Aissaoui O, Barrou L, El Kettani EHC, Nsiri A, Al Harrar R, et al. Nutritional status assessment in patients with Covid-19 after discharge from the intensive care unit. Clin Nutr ESPEN. 2021;41:423-8.

46. Mao L, Jin H, Wang M, Hu Y, Chen S, He Q, Chang J, Hong C, Zhou $Y$, Wang D, et al. Neurologic manifestations of hospitalized patients with coronavirus disease 2019 in Wuhan, China. JAMA Neurol. 2020;77(6):683-90.

47. Nordvig AS, Fong KT, Willey JZ, Thakur KT, Boehme AK, Vargas WS, Smith CJ, Elkind MSV. Potential neurologic manifestations of COVID-19. Neurol Clin Pract. 2021;11(2):e135-46.

48. Mastrangelo A, Bonato M, Cinque P. Smell and taste disorders in COVID19: from pathogenesis to clinical features and outcomes. Neurosci Lett. 2021;748:135694.

49. Javid Mishamandani Z, Norouzy A, Hashemian SM, Khoundabi B, Rezaeisadrabadi M, Safarian M, Nematy M, Pournik O, Jamialahmadi T, Shadnoush M, et al. Nutritional status of patients hospitalized in the intensive care unit: a comprehensive report from Iranian hospitals, 2018. J Crit Care. 2019:54:151-8.

50. Fan E, Dowdy DW, Colantuoni E, Mendez-Tellez PA, Sevransky JE, Shanholtz C, Himmelfarb CR, Desai SV, Ciesla N, Herridge MS, et al. Physical complications in acute lung injury survivors: a two-year longitudinal prospective study. Crit Care Med. 2014;42(4):849-59.

51. Denehy L, Berney S, Whitburn L, Edbrooke L. Quantifying physical activity levels of survivors of intensive care: a prospective observational study. Phys Ther. 2012;92(12):1507-17. 
52. Herridge MS, Cheung AM, Tansey CM, Matte-Martyn A, Diaz-Granados N, Al-Saidi F, Cooper AB, Guest CB, Mazer CD, Mehta S, et al. One-year outcomes in survivors of the acute respiratory distress syndrome. N Engl J Med. 2003;348(8):683-93.

53. van der Schaaf $M$, Beelen A, Dongelmans DA, Vroom MB, Nollet F. Poor functional recovery after a critical illness: a longitudinal study. J Rehabil Med. 2009;41(13):1041-8.

54. Lund LC, Hallas J, Nielsen H, Koch A, Mogensen SH, Brun NC, Christiansen CF, Thomsen RW, Pottegård A. Post-acute effects of SARS-CoV-2 infection in individuals not requiring hospital admission: a Danish population-based cohort study. Lancet Infect Dis. 2021;21(10):1373-82. https://doi.org/10.1016/\$1473-3099(21) 00211-5.

55. Cohen ML. Changing patterns of infectious disease. Nature. 2000;406(6797):762-7.

56. Wu C, Chen X, Cai Y, Xia J, Zhou X, Xu S, Huang H, Zhang L, Zhou $X$, Du C, et al. Risk factors associated with acute respiratory distress syndrome and death in patients with coronavirus disease 2019 pneumonia in Wuhan, China. JAMA Intern Med. 2020;180(7):934-43.

57. Barazzoni R, Bischoff SC, Breda J, Wickramasinghe K, Krznaric Z, Nitzan D, Pirlich M, Singer P. Endorsed by the EC: ESPEN expert statements and practical guidance for nutritional management of individuals with SARS-CoV-2 infection. Clin Nutr. 2020;39(6):1631-8.

58. Miller R, Englund K. Clinical presentation and course of COVID-19. Clevel Clin J Med. 2020;87(7):384-8

59. Wischmeyer PE. Nutrition therapy in sepsis. Crit Care Clin. 2018;34(1):107-25

60. Martinez Garcia RM, Jimenez Ortega Al, Lopez Sobaler AM, Ortega RM. Nutrition strategies that improve cognitive function. Nutr Hosp. 2018;35(Spec No6):16-9.

61. Beilharz JE, Maniam J, Morris MJ. Diet-induced cognitive deficits: the role of fat and sugar, potential mechanisms and nutritional interventions. Nutrients. 2015;7(8):6719-38.

62. Blusztajn JK, Slack BE, Mellott TJ. Neuroprotective actions of dietary choline. Nutrients. 2017:9(8):815. https://doi.org/10.3390/nu9080815.

63. Owen L, Corfe B. The role of diet and nutrition on mental health and wellbeing. Proc Nutr Soc. 2017;76(4):425-6.

64. Cook R, O'Dwyer N, Parker H, Donges C, Cheng H, Steinbeck K, Cox E, Franklin J, Garg M, Rooney K, O'Connor H. Iron deficiency anemia, not iron deficiency, is associated with reduced attention in healthy young women. Nutrients. 2017;9(11):1216.

65. Connor WE. Importance of n-3 fatty acids in health and disease. Am J Clin Nutr. 2000;71(1 Suppl):171S-175S.

66. Derbyshire E. Do omega-3/6 fatty acids have a therapeutic role in children and young people with ADHD? J Lipids. 2017;2017:6285218.

67. Miller JW, Harvey DJ, Beckett LA, Green R, Farias ST, Reed BR, Olichney JM, Mungas DM, DeCarli C. Vitamin D status and rates of cognitive decline in a multiethnic cohort of older adults. JAMA Neurol. 2015:72(11):1295-303.

68. Warthon-Medina M, Moran VH, Stammers AL, Dillon S, Qualter P, Nissensohn M, Serra-Majem L, Lowe NM. Zinc intake, status and indices of cognitive function in adults and children: a systematic review and meta-analysis. Eur J Clin Nutr. 2015;69(6):649-61.

69. Jacka FN, Mykletun A, Berk M, Bjelland I, Tell GS. The association between habitual diet quality and the common mental disorders in community-dwelling adults: the Hordaland Health study. Psychosom Med. 2011;73(6):483-90.

70. Jacka FN, Pasco JA, Mykletun A, Williams LJ, Hodge AM, O'Reilly SL, Nicholson GC, Kotowicz MA, Berk M. Association of Western and traditional diets with depression and anxiety in women. Am J Psychiatry. 2010;167(3):305-11

71. Sanchez-Villegas A, Delgado-Rodriguez M, Alonso A, Schlatter J, Lahortiga F, Serra Majem L, Martinez-Gonzalez MA. Association of the Mediterranean dietary pattern with the incidence of depression: the Seguimiento Universidad de Navarra/University of Navarra follow-up (SUN) cohort. Arch Gen Psychiatry. 2009;66(10):1090-8.

72. Devassy JG, Leng S, Gabbs M, Monirujjaman M, Aukema HM. Omega-3 polyunsaturated fatty acids and oxylipins in neuroinflammation and management of Alzheimer disease. Adv Nutr. 2016;7(5):905-16.

73. Miquel S, Champ C, Day J, Aarts E, Bahr BA, Bakker M, Banati D, Calabrese V, Cederholm T, Cryan J, et al. Poor cognitive ageing: vulnerabilities, mechanisms and the impact of nutritional interventions. Ageing Res Rev. 2018;42:40-55.

74. Schlogl M, Holick MF. Vitamin D and neurocognitive function. Clin Interv Aging. 2014;9:559-68.

75. Durga J, van Boxtel MP, Schouten EG, Kok FJ, Jolles J, Katan MB, Verhoef P. Effect of 3-year folic acid supplementation on cognitive function in older adults in the FACIT trial: a randomised, double blind, controlled trial. Lancet. 2007;369(9557):208-16.

76. Aparicio Vizuete A, Robles F, Rodriguez-Rodriguez E, Lopez-Sobaler AM, Ortega RM. Association between food and nutrient intakes and cognitive capacity in a group of institutionalized elderly people. Eur J Nutr. 2010;49(5):293-300.

77. Bourre JM. Effects of nutrients (in food) on the structure and function of the nervous system: update on dietary requirements for brain. Part 2: macronutrients. J Nutr Health Aging. 2006;10(5):386-99.

78. Kim SH, Park YM, Choi BY, Kim MK, Roh S, Kim K, Yang YJ. Associations of serum levels of vitamins $A, C$, and $E$ with the risk of cognitive impairment among elderly Koreans. Nurs Res Pract. 2018;12(2):160-5.

79. Markiewicz-Zukowska R, Gutowska A, Borawska MH. Serum zinc concentrations correlate with mental and physical status of nursing home residents. PLOS ONE. 2015;10(1):e0117257.

80. Andruchow ND, Konishi K, Shatenstein B, Bohbot VD. A lower ratio of omega- 6 to omega-3 fatty acids predicts better hippocampus-dependent spatial memory and cognitive status in older adults. Neuropsychology. 2017;31(7):724-34

81. Guo XM, Liu H, Qian J. Daily iron supplementation on cognitive performance in primary-school-aged children with and without anemia: a meta-analysis. Int J Clin Exp Med. 2015;8(9):16107-11.

82. Bourre JM. Effects of nutrients (in food) on the structure and function of the nervous system: update on dietary requirements for brain. Part 1: micronutrients. J Nutr Health Aging. 2006;10(5):377-85.

83. Scarmeas N, Anastasiou CA, Yannakoulia M. Nutrition and prevention of cognitive impairment. Lancet Neurol. 2018;17(11):1006-15.

84. Seetharaman S, Andel R, McEvoy C, Dahl Aslan AK, Finkel D, Pedersen NL. Blood glucose, diet-based glycemic load and cognitive aging among dementia-free older adults. J Gerontol A Biol Sci Med Sci. 2015;70(4):471-9.

85. Katsiardanis K, Diamantaras AA, Dessypris N, Michelakos T, Anastasiou A Katsiardani KP, Kanavidis P, Papadopoulos FC, Stefanadis C, Panagiotakos DB, et al. Cognitive impairment and dietary habits among elders: the Velestino Study. J Med Food. 2013;16(4):343-50.

86. Kesse-Guyot E, Andreeva VA, Lassale C, Ferry M, Jeandel C, Hercberg S, Galan P, Group SVMR. Mediterranean diet and cognitive function: a French study. Am J Clin Nutr. 2013;97(2):369-76.

87. Gardener S, Gu Y, Rainey-Smith SR, Keogh JB, Clifton PM, Mathieson SL, Taddei K, Mondal A, Ward VK, Scarmeas N, et al. Adherence to a Mediterranean diet and Alzheimer's disease risk in an Australian population. Transl Psychiatry. 2012;2:e164.

88. Tsivgoulis G, Judd S, Letter AJ, Alexandrov AV, Howard G, Nahab F, Unverzagt FW, Moy C, Howard VJ, Kissela B, et al. Adherence to a Mediterranean diet and risk of incident cognitive impairment. Neurology. 2013;80(18):1684-92.

89. McEvoy CT, Guyer H, Langa KM, Yaffe K. Neuroprotective diets are associated with better cognitive function: the health and retirement study. J Am Geriatr Soc. 2017;65(8):1857-62.

90. Batty GD, Deary IJ, Luciano M, Altschul DM, Kivimaki M, Gale CR. Psychosocial factors and hospitalisations for COVID-19: prospective cohort study based on a community sample. Brain Behav Immun. 2020;89:569-78.

91. Brugliera L, Spina A, Castellazzi P, Cimino P, Arcuri P, Negro A, Houdayer E, Alemanno F, Giordani A, Mortini P, et al. Nutritional management of COVID-19 patients in a rehabilitation unit. Eur J Clin Nutr. 2020;74(6):860-3

92. Casagrande M, Favieri F, Tambelli R, Forte G. The enemy who sealed the world: effects quarantine due to the COVID-19 on sleep quality, anxiety, and psychological distress in the Italian population. Sleep Med. 2020;75:12-20

93. Chew NWS, Lee GKH, Tan BYQ, Jing M, Goh Y, Ngiam NJH, Yeo LLL, Ahmad A, Ahmed Khan F, Napolean Shanmugam G, et al. A multinational, multicentre study on the psychological outcomes and 
associated physical symptoms amongst healthcare workers during COVID-19 outbreak. Brain Behav Immun. 2020;88:559-65.

94. Forte G, Favieri F, Tambelli R, Casagrande M. The enemy which sealed the world: effects of COVID-19 diffusion on the psychological state of the Italian population. J Clin Med. 2020;9(6):1802.

95. Huang $Y$, Zhao N. Generalized anxiety disorder, depressive symptoms and sleep quality during COVID-19 outbreak in China: a web-based cross-sectional survey. Psychiatry Res. 2020;288:112954.

96. Lesser IA, Nienhuis CP. The impact of COVID-19 on physical activity behavior and well-being of Canadians. Int J Environ Res Public Health. 2020;17(11):3899.

97. Kang L, Ma S, Chen M, Yang J, Wang Y, Li R, Yao L, Bai H, Cai Z, Xiang Yang B, et al. Impact on mental health and perceptions of psychological care among medical and nursing staff in Wuhan during the 2019 novel coronavirus disease outbreak: a cross-sectional study. Brain Behav Immun. 2020;87:11-7.

98. Lai X, Wang M, Qin C, Tan L, Ran L, Chen D, Zhang H, Shang K, Xia C, Wang S, et al. Coronavirus disease 2019 (COVID-2019) infection among health care workers and implications for prevention measures in a Tertiary Hospital in Wuhan, China. JAMA Netw Open. 2020;3(5):E209666.
99. Tan BYQ, Chew NWS, Lee GKH, Jing M, Goh Y, Yeo LLL, Zhang K, Chin HK, Ahmad A, Khan FA, et al. Psns for prevention measures in a Tertiary Hospital in Wuhan, psychological impact of the COVID-19 pandemic on health care workers in Singapore. Ann Intern Med. 2020;173(4):317-20.

100. Varatharaj A, Thomas N, Ellul MA, Davies NWS, PollakTA, Tenorio EL, Sul$\tan$ M, Easton A, Breen G, Zandi M, et al. Neurological and neuropsychiatric complications of COVID-19 in 153 patients: a UK-wide surveillance study. Lancet Psychiatry. 2020;7(10):875-82.

101. Wang CY, Pan RY, Wan XY, Tan YL, Xu LK, Mclntyre RS, Choo FN, Tran B, Ho R, Sharma VK, et al. A longitudinal study on the mental health of general population during the COVID-19 epidemic in China. Brain Behav Immun. 2020;87:40-8.

102. Zhang WR, Wang K, Yin L, Zhao WF, Xue Q, Peng M, Min BQ, Tian Q, Leng $\mathrm{HX}, \mathrm{Du} \mathrm{JL}$, et al. Mental health and psychosocial problems of medical health workers during the COVID-19 epidemic in China. Psychother Psychosom. 2020;89(4):242-50.

\section{Publisher's Note}

Springer Nature remains neutral with regard to jurisdictional claims in published maps and institutional affiliations.
Ready to submit your research? Choose BMC and benefit from:

- fast, convenient online submission

- thorough peer review by experienced researchers in your field

- rapid publication on acceptance

- support for research data, including large and complex data types

- gold Open Access which fosters wider collaboration and increased citations

- maximum visibility for your research: over 100M website views per year

At BMC, research is always in progress.

Learn more biomedcentral.com/submissions 